IRA-International Journal of Management \& Social Sciences

ISSN 2455-2267; Vol.07, Issue 02 (2017)

Pg. no. 148-155

Institute of Research Advances

http://research-advances.org/index.php/RAJMSS

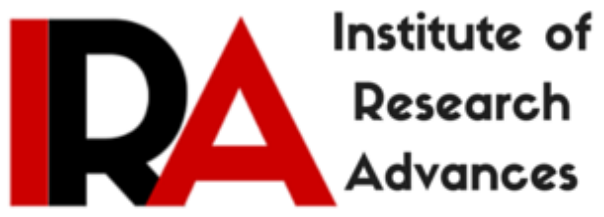

\title{
Forts in Western Vidarbha
}

\section{Dr. Nalini K. Tembhekar}

Associate Professor, Department of History, Government Vidarbha Institute of Science \& Humanities, Amravati, India.

Type of Review: Peer Reviewed.

DOI: http://dx.doi.org/10.21013/jmss.v7.n2.p4

How to cite this paper:

Tembhekar, N. (2017). Forts in Western Vidarbha. IRA-International Journal of Management \& Social Sciences (ISSN 2455-2267), 7(2), 148-155. doi:http://dx.doi.org/10.21013/jmss.v7.n2.p4

(C) Institute of Research Advances

(cc) BY-NC

This work is licensed under a Creative Commons Attribution-Non Commercial 4.0

International License subject to proper citation to the publication source of the work.

Disclaimer: The scholarly papers as reviewed and published by the Institute of Research Advances (IRA) are the views and opinions of their respective authors and are not the views or opinions of the IRA. The IRA disclaims of any harm or loss caused due to the published content to any party. 


\begin{abstract}
Forts have played a prominent role in the military system of any Kingdom in Medieval Period. So the Bahmanis did much for military architecture as they had powerful enemies on all sides. Gawilgarh and Narnala are the significant forts of Bahmani Sultanate. These forts are regarded as the greatest and most abiding monuments and superior to European forts of the same period (Circa 1350-1500). Grawilgarh and Narnala in Berar are examples of engineering skill and architecture appropriate for mountain strong holds of good taste and lavish expenditure. Combined with elegant stone carving. The carving of the forts gate at Narnala and Gawilgarh are still in good preservation.

Balapur fort was a fair specimen of later Mughal architecture. The fort too was keeping in mind the town's (Balapur) military responsibilities and position. Balapur hailed as an important military station during the times of the Mughals. Complex architecture used in the fort ensured its safety, as well as eased the discharge of missiles and other ammunition from within the fort rendering it one of the most impenetrable forts in vidarbha region.
\end{abstract}

\title{
Introduction
}

Vidarbha is the eastern region of the Indian state of Maharashtra, Comprising Nagpur division and Amravati division. Amravati division alias western vidarbha is formerly known as Berar. Before the Mughal Occupation or was part of the Nizam Shahi Sultanate of Ahmadnagar, it was ceded to the emperor Akbar by Chand Bibi in 1596. In 1636, The Mughal Possessions in Deccan were divided into 4 subaha, Berar Subhah was one of them with Ellichpur as its capital and Gavilgad as its main fort. In 1724, the Nizam-ul-Mulk Asif Jah established his independent kingdom at Hyderabad and later claimed his Sovereign rights over Berar with exception of certain districts (Mehkar, Umarkhed etc.) ceded to the Maratha Peshwa in 1760 and 1795. The claim was contested by the Maratha Bhonsale Rajas of Nagpur, and for more than half a century the country was devastated by wars between the two.

This condition of things was ended by wellesleys victories at Assaye and Argaon (1803) which forced the Bhonsale's of Nagpur to cede his territories south of Gawilgarh and Narnala fort and east of the Wardha river. The fort Gawilgarh and Narnala remained subject of Bhonsale's of Nagpur. The above cited forts and the Balapur fort played an important role in the history of medieval period of this region.

\section{Gawilgarh Fort}

Gawilgarh is a well-fortified mountain strong hold north of the Deccan plateau, in the vicinity of Melghat tiger reserve, Amravati District, in Maharashtra. The fort area is surrounded on all the sides except the north by precipitous slopes.

On the north it is connected by a narrow ridge like feature with the Chikhaldara Plateau. A very remarkable feature of this ridge is that the descent from the relatively flat summit plateau is by a series of precipitous slopes one below the other separated by narrow steps of lesser gradients, most conspicuous on the slopes of the plateau of Vairat, Chikhaldara and Gawilgarh fort area.

The fort is in round shape and surrounded the area near about 10 to $12 \mathrm{~km}$. and may be the biggest fort of south India in extension. Now there are many shattered buildings, lakes, temples, mosques and tombs scattered everywhere.

It is said that, this fort was built by the Gawlis, who were rulers of the Shepherd Community in the $12^{\text {th }} / 13^{\text {th }}$ century. Earlier it was just made of mud. Later on the fort came under the reigns of the Gond Community, till the time they were defeated by the Mughals, and then it came under the rule of Marathas. It has bravely endured the sensational battles and today its ramparts remain tranquil and deserted. The fort is currently under the Melghat tiger project.

The exact date of construction of the existing fort is not known but the persian historian, Firishta, records that Ahmed Shah Wali, the ninth King of the Bahamani dynasty, built Gawilgarh 
when he was encamped at Ellichpur in $1425 .{ }^{1}$ Likely this was the date when major fortification was carried out. It was subsequently repaired and improved by Fateh-Ullah Imadul-Mulk, who was governor of Gawil. Taking advantage the disintegration of the Bahmini Sultanate, he captured all Berar, Proclaimed his independence and founded the Imad Shahi dynasty of Berar Sultanate in 1490. Than Berar was invaded by Murtaza Nizam Shah (1565-1588) of Ahmednagar in $1574 \mathrm{AD}^{2}$. He appointed Bahram Khan, as commandant of the fort in 1577. He also repaired the fort. Then it remained under the control of Bhonsale of Nagpur and then it was captured by Britishers. The fort combined two forts, an outer and an inner. It was always believed that the outer fort was to deter an attacking enemy while those inside retreated to the inner fort, which was protected by a ravine, and only had one entrance, only accessible through a gate house, Via a narrow twisting corridor. The Outer fort was considered more of a decay, and behind that lay a ravine, across which lay the gate to the Inner Fort. The Inner fort was protected by several gates, the first of which was the least defensible. After breaking through that first gate, however, an assaulting army would turn sharply to the left and follow a narrow passage up to a second gate, all the while being attacked by the defenders from above.

Once a magnificent structure, the fort has been reduced to a dilapidated structure now. The most conspicuous of the remains upon the hill is the great masjid which stands upon the highest point towards the south side of the plateau. The mosque has seven arches in its facade and was three bays deep from front to back. All along, above the arches, runs an overhanging cornice of simple design. Three fourth of which have been destroyed. Each end of the façade is flanked by a projecting square pire; put these, instead of being surmounted by minars, as elsewhere, carry above the roof most elegant little square Canopies or Chhatris with deep cornices, rich brackets and perforated jail or Screen work in each of their four sides. The Chhatri from the south pier is missing; that on the north remains, but is damaged. A flight of steps descend from the mosque to the great square courtyard having a great gateway on the east and smaller entrances on the north and south.

A small amount of blue tiling has been used on the face of the masque ${ }^{3}$, but at some later period a tomb has been built before this and with its flanking walls. There is also a small and substantially built masque stands on the edge of a large tank, a short distance to the north-east of great mosque.

The fort has seven gates and has inscriptions in Persian recording the date of building of each gate. Among them Delhi darwaza is significant. It is between the inner and the outer fort. Behind it there is a 'Burjaband Darwaza', in western side, there is 'Wastapur' darwaza and the 'Pir Patha' darwaza, the south western gate of the fort. Above the latter are the remains of an inscription, which tells us that Fateh-Ullah Imad-Ul-Mulk, rebuilt 'Jami Masjid' with the old stones in 1488 AD. Above the tank is in the reign of Mohmud Shah Bahmani. This inscription evidently refers to the repairing of the great mosque. The Delhi gate has a group of sculptured symbols on its face, above the archway. In the centre is a palm tree, and on either side of this and below it a lion passant, looking in ward with a small elephant below each paw. Above the lion, on each side, is an eagle displayed, double-headed, holding in each of its beaks a small elephant.

In the western face of the fort is a fine bastin with an inscription which contained that, in Gawil Bahram built a bastion. Bahram Khan was commandant of Gawilgarh under Saiyid Murtaza Subzawari, Murtaza.

Nizam Shah's governor of Berar, and the fort was repaired in 1577 owing to the prevalence of a rumour that Akbar was then marching on Berar. What is known as the outer fort of Gawilgarh, which lies between the Delhi derwaza and the deserted village of Labada, was probable built by the Bhonsla Rajas of Nagpur.

It takes a whole day to see the fort. By using the slope of deep valley from south to north, five lakes have been built named Bhimtalao, Khambtalao, Devitalao and Dhobitalao, many of them are full with water still now. The Shakkar lake is believed to possess medicinal properties that can cure 
certain diseases. There is a building named Rani Zarokha. It is beautifully constructed and a Symbol of Hindu-Muslim architecture, it is said that Britishar's attacked on the buildings like Darbargruh, Sabhagruh etc. during the revolt of 1857 , so that the revolutionaries shouldn't take the resort of Gawilgarh fort $^{5}$. There are many vaults under the main buildings.

It had been used as a treasury of Bhonsale. There are 10 Cannons in the fort. They are made of iron, copper and brass. Two of them, named 'Kalbhairav' and 'Billie' are of considerable in Size. The first one is 19 feet, and second is 16 feet long.

In British era during the second Anglo-Maratha war, in 1803, Britishers had to take great efforts to conquer this fort. The in-change of the fort of Bhonsale's named 'Benisingh' fought very furiously and died in front of the gate but he didn't surrender till his death. It was one of the centre place of the politics of vidarbha and Berar in medieval period.

\section{Capture of Gawilgarh by British}

At the time Gawilgarh was considered unassailable and the defenders believed they could hold the mountain fort regardless of whatever the British Army threw at it. But on $15^{\text {th }}$ December 1803, during the second Anglo Maratha war British forces under the command of sir Arthur Wellesley defeated of the forces of Raghoji II Bhosale, Rajah of Berar. Gawilgarh's garrison of 3000 was commanded by killa-dar Bonisingh, assisted by manoo Bapu.

When Arthur Wellesley's army attacked Gawilgarh, Lieutenant Colonel Kenny of the $11^{\text {th }}$ Regiment of foot succeeded in taking the outer fort, and led the assault on the inner fort, supported by flank companies of the $94^{\text {th }}$ Regiment of foot and sepoys from Major General James Steven son's division. At the same time, the $74^{\text {th }}$ and $78^{\text {th }}$ highlanders diverted the attention of the defenders by false attacks from the south.

The British sent in wave after wave to capture the gate house of the inner fort, and were slaughtered. The narrow twisting corridor housed there doors to gain access to the inner fort, and the walls above the corridor were heavily defended, and the Maratha forces threw rockets and musket fire at the approaching British troops. After three waves, the assault looked deomed, until captain Campbell and his $94^{\text {th }}$ Light infantry discovered a difficult, but accessible way to climb the inner walls, and British were successful in fighting the Maratha forces around the gate house from behind, and opened up the doors to the awaiting forces outside ${ }^{6}$.

By the end of the day Gawilgarh had fallen, and British won the battle, they had lost to 132 soldiers, while the Maratha had suffered the loss close to 1200 including the deaths of Benisingh and manoo Bapu. The fall of Gawilgarh ended the second Anglo-Maratha war. The British did return the fort to the Maratha Empire, but it was never restored or used as a stronghold again.

\section{Narnala Fort}

Narnala also known as 'Shanur fort' is a hill fort in Maharashtra. It is situated on an isolated hill of Satpuda range in Akot, district Akola in Amravati division. It Stands 3000 feet above the mean sea level and covers an area of 362 acres. It had played an important role in the medieval history of the deccan.

The fort was built between three hills, Jaffarabad in the north, Narnala in the centre and Taligad in the south. They are grouped together under fort Narnala, because Jaffarabad and Taligad did not have distinct fortifications of their own and were not independently defensible.

According to tradition, the fort was first established in $10 \mathrm{AD}$, by Gond kings and named after Rajput ruler Narnal Singh. Ahmad Shah Bahamani (1422-1436) got the fort repaired around 1425 when he 
constructed Gawilgarhfort with a view to obstructing the invaders from the north frontier of his kingdom ${ }^{7}$. The fort passed on the Fatehulla Imad-ul-mulk when he became an independent ruler by 1490. He was the Subhedar of Berar under the Bahamanis. The fort was under various dynasties like Bahamani (1347-1490 AD.), Imad Shahi (1490-1572 AD.), Nizam Shahi Mughals (1526-1707 AD.) Marathas (1674-1818 AD) and Nizam of Hyderabad (1724) and East India Company to over it in 1818 AD.Narnala fort was handed over to British according to the treaty of January 6, 1818 entered into by East India Company and Second Mudhoji, alias Appasaheb Bhosale.

In 1437, when Nasir Khan the Subhedar of Khandesh invaded Berar, the governor of the province remained loyal to his master, Ala-ud-din Ahmad Shah II (Son of Ahmad Shah I Wali) and retreated to Narnala. He was besieged by disaffected nobles and Nasir Khan, but Managed to break through the besieging force with help of Khalaf Hasan Basri who was sent by Ala-ud-din Ahmed Shah II and Nasir Khan was defeated.

In 1487, Narnala along with Gawilgarh came under the control of Fathullah Imad-ul-Mulk, the founder of Imad Shahi dynasty at Ellichpur.

In 1572 Burhan Imad Shah (also of the Imad Shahi dynasty) was imprisoned in Narnala by one of his Amirs Tufalkhan who crowned himself. This gave Murtaza Nizam shah of Ahmednagar (1565-1588) a pretext to lay siege to the fortress. In the battle that was fought between Tufalkhan and Murtaza Nizam shah in 1572.Tafalkhan was defeated and had to flee and took asylum with Muhammad Shah of Khandesh. On being threatened by Murtaza Nizam shah of Ahamadnagar, Muhammad Shah of Khandesh, refused to give, refuge to Tufalkhan and he had to return to Narnala fort. The fort was invested by the army of Murtaza. The fort surrendered, Tufalkhan and also Burhan Imad Shah were imprisoned, subsequently putting them to death. Thus the fort passed into the hands of the Ahmednagar kings ${ }^{8}$.

On January 26, 1597 the battle was fought between the armies of the Ahmednagar kingdom and the Emperor Akbar, in which the armies of Adilshahi Emperor who along with the Kutub Shah of Golconda, was an ally of Nizam shah emerged successful. However Khan Khanan defeated sohelkhan and sent his army for the capture of Narnala and Gawilghur. Then Abul Fazal was appointed in his place. He captured Narnala and most of the forts in this areain 1597-98. Akbar had divided his kingdom into 15 subhas. Narnala was one of the Sarkars of Berar Subah during his rule and renamed as Shanur?.

The fort passed on afterwards to the Marathas. After the return of Shahu to the Deccan in 1707, Parsoji Bhosale was the first Maratha noble who joined hands with shahu on the western border of Berar and a Jagir was conferred upon him which included Sarkar Narnala. The fort passed on the Nizam again and finally to the British but throughout all this history no great fight ever took place over it.

It is also the birth place of Aurangzeb's great grand son. Sardar Beg Mirza and Qader Beg Mirza hereditary descendants of the Mughal dynasty in the $18^{\text {th }}$ Centuty, stayed near Argaon because Shah beg Subedar of Berar was holding the fort.

In 1803 the fort was under the possession of Bhosales of Nagpur. On 28 November 1803, the war was fought between the Bhosale and British at Argaon, and according to the treaty of Deogaon, Berar was handed over to the British by Bhosale's of Nagpur.

\section{Main Features}

The forts are enclosed except in those places where the natural escarpment of rock renders artificial defenses unnecessary by crenellated stone walls, well and strongly built. The fort has 360 buruj (bastions), four large and twenty-two small gates. The large gates are called the Delhi darvaza, the Shahanur darvaza. The entrance of the fort consists of three separate gate-ways on the same path. The main entrance to the fort is Shahnoor gate and a very plain structure. The ornaments on this gate 
way are two lions, facing inwards, just as they are found on the old Gond fort of Chandrapur. It is flanked by walls and bastions built of cyclopean masonry some of the great blocks being over six feet long. These are laid upon one another with very clean joints and their surfaces are cleanly dressed. Some of the kanguras or merlons of the battlements are of single stones, one that was measured being four feet five inches high by three feet seven inches broad. A curtain wall of this same heavy masonry projects upon the outer side of the gateway and thus screens and protects it from below. It seems that this other gale way is of an earlier date than the innermost gateway of the same entrance. The second gateway of the entrance is the Mehandi darvaza. It is probably of the same date as the outer gateway.

\section{Mahakali Gate}

The third and innermost gate way is the best piece of work in the fort. The Hindus call it 'Mahakali Gate' while the Muslims have named it 'Mohammadi gate'.The gate was constructed by Fathullah-Imadut Mulk, the subedar of Berar, in the reign of Shahabuddin Mahmud Bahmani ${ }^{\mathbf{1 0}}$. It consists of the great entrance archway, 19 feet from the ground to the apex of the arch and 10 feet 6 inches wide. The whole height of the gateway is 37 feet 3 inches ${ }^{11}$. It has a heap of rough stones daubed with red pigment and oil in one of its galleries and locally known as 'Raja Ilal (a possible reference to the eponymous Raja Ilal of Ellichpur). Mahakali Gateway is flanked oneither side by galleries and guardrooms. Upper portion of the gateway comprises two large inscriptions belonging to Bahamani period. The upper one states the construction of the gate in hijra year 892 (1487 AD.) While the lower blesses the Gazi Sultan Shahab-Ud-Duniya Waddin Muhamud Shah ${ }^{\mathbf{1 2}}$.

The gateway has also two beautiful balconies. The lattice work on the balconies constitutes the chief architectural feature of the gate. In the words of Haig, the gate is "the most interesting and historically the most important monument in the fort, and will call for further notice ${ }^{\mathbf{1 3}}$. This gateway is one of the most beautiful specimens of the Indo-Muslim Deccani architecture of Berar.

Between the last two gateways are the domed tombs of Bagh Savar Wali and Gaz Badshah Wali. The former Named Hazrat Burhanuddin was a great Muslim Saint and it is said that many white tigers were seen with the hazrat at that time.

\section{Ambar Bangla}

The Ambar Bangla is located near the passing of the last gate way, which was the 'Kacheri' of former days. It is a lofty building looking on to a cemented courtyard which formerly contained a fountain and was roofed with wood. The bangla had a flat roof reached by a long and steep staircase, and walls around the roof give shade during the greater part of the day. Just across the courtyard, there is a tomb of Burhanuddin some times called 'the days temple' the tomb has a stone platform with a few tomb stones upon it. It has long been known as a place where the bite of a mad dog, jackal may be cured. People come from various places even from a distance. There is a 'Shakkar Talao' behind the temple. Possessing some medicinal properties, a tank of some little size. There are twenty two tanks in the fort and six of them still hold water all through the year. At the west end of the courtyard, There is a mosque and stables, and another end is a block of four large covered cisterns. Some have thought them to be Jain water- cisterns, but they are locally called telache tupache take and are said to have been used for string oil and ghee for the large garrison.

On the top of the hill is the dargah of Saiduliboa or Saiduliwali, There is a place here named Sati Maidan, vast numbers of men were killed here in the time of Aurangzeb. Among the buildings on the east side is a Nagar-Khana where prisoners are said to have been kept in a pit, with a big stone over their heads, to await execution. A few hundred yards off is the 'Khuni Buruj' where a platform was built on the edge of sheer precipice over which criminals were sometimes hurled.

The 'Nuugai Toph' nine-yard gun is said to have been placed there during the reign of Aurangzeb in 1670 and it bears an inscription, in Persian. This is a 18 foot long cannon with a diameter of six feet had a reach of seven miles. There was a sister gun called 'Khadak Bijli' but it fell over the cliff into 
Chandan Khora, the valley of Sandal Wood. It is said that Adli Beg or Atalu Beg erected many Arabic Scripts and the Toph named 'Khadak Bijli'. Two other guns lie near the Akot gate, to the south of the ordinary entrance, but the bulk of the military stores were removed in 1858. Tatya Tope and others were then at Jalgaon, and it was thought that they might seize these stores, though the fort was in the hands of the Nizam ${ }^{14}$.

The Dhobi Talao is a tank which holds water all the year. It was a series of arches at one side with summer houses, consisting of two stone chambers one above the other and covered by a flat roof. Water was taken thence to a garden. There is a Shrine of Mahatoba on the south of the tank, is famed for the cure of snake-bite. Rani Mahal is a plain solid structure with a three arched front and roof of vaulted bays resting on heavy square columns. It is said that the Bhosles had 2,000 or 2,500 men here and the number and variety of building show clearly that there must have been a large population. The fort is now in dilapidated condition and there is a need to preserve it for next generations.

\section{Balapur Fort}

Balapur Fort is located in the Balapur town, which is 25 kilometers for from Akola district. It is situated at the junction of Mhais river and Man rivar. The construction of the present fort was started by Azam Shah, the son of Emperor Aurangzeb and was completed by Ismail Khan, the Navab of Ellichpur in 1757 under the Nizam ${ }^{15}$. It is massively built of bricks and the strongest fort in Berar. Prior to the construction of the fort there was an earthen gadhi constructed by the Rajput Akol Singh. Balapur was the chief military station of the Mughals in Berar after Ellichpur (Achalpur). The temple of BalDevi from which the town has derived its name, lies just under the fort on the southern side. Since Balapur was an important military station during the Mughal period, this fort was constructed keeping in mind about the military position and responsibility. It consists of an inner and outer fort, the former rising by whole hight of its walls above the latter, Both the outer and the inner forts are entered by fine Moghal gateways. The fort has three gateways, one within the other. Above the gateway of the outer fort is an inscription, which indicates that the fort was completed in AD 1757 by Ismail Khan, the first Nowab of Ellichpur under the Nizam. The middle one has doors studded in their upper parts with long spikes to resist elephants. The inner most one has elephants and a house, besides some flowers, cut in the stone beside it. The highest and innermost walls are ten feet thick and their ramparts are pierced with numerous slits at three different angles for the discharge of missiles.

Inside the fort are one mosque and three wells. There is a stone stand for a flag staff, to carry a Muhammedan ensign; but on the other hand, it is said that a tomb and a flag were in honour of the Muhammedan saint Chand Khan.

There is a Chhatri (umbrella shaped pavilion) in the fort, said to have been constructed by Raja Jaysing who was the Governor of the Deccan after Aurangzeb ascended the throne. It is a 25 feet square and has a height of 33 feet. Its foundations were much damaged in a great flood which occurred more than 100 years ago, but after some years the damage was repaired at a cost of Rs. 3,000 received from Jaipur ${ }^{16}$. It is a graceful building of black stone on a high plinth. It is surmounted by five domes, one large one in the centre, over the square, surrounded by four small ones. The superstructure is supported by twenty pillars and lintels. The ornament is principally of the leaf and dart pattern with conventional lotus flowers, and the interior of the domes is fine. A flight of steps formerly led down to the river, but these have since disappeared. At present the fort is used by the government to run some of its offices, and lost its glory due to lack of maintenance.

\section{History}

Balapur is a historical town mentioned in Ain-I-Akbari as one of the richest paraganas in the Subha of Berar. Berar Province was made over to the Moghals by the agreement that Chandbibi of Ahmadnagar entered into with Murad, the son of Akbar. Murad accompanied by Khankhanon Settled at Balapur and established the town of Shahapur (now in Buldhana district) in 1595. In 1616, Shahanavazkhan, the Subhedar of Berar was camping at Balapur. He defeated Malik Amber attaeking 
him near Kirkee by way of Rohinkheda pass. But he could not hold for long and had to Balapur, Aurangzeb, after ascending the imperial throne at Delhi, appointed Raja Jaysing as the Governor of the Deccan. Mirza Azam Shah, Son of Aurangzeb, is said to have lived here and to have built a mud fort.

In 1720, a battle was forght between Nizam-ul-Mulk Maratha and the Moghals, 7-8 miles west of the town, called battle of Balapur. In this battle Sambhaji of Kolhapur and Chandrasen Jadhav who were opposed to Shahu took the side of the Nizam while Shahu had ordered Santaji Shinde, Khanderv Dabhade, Damaji Gaikwad, Shankraji Malhar, Kanhoji Bhosle and others to go to the aid of Alam Ali Khan the Mughal Sardar who was later slain on the battlefield. Shankarji Malhar died of the wounds he received in the battle field ${ }^{17}$.

\section{Conclusion}

Gawilgarh, Narnala and Balapur Forts played a prominent role in the politics of Vidarbha region as they are the military centers of various dynasties. These are the armoury, ammunition and weapons were kept in it. Most of the part of these forts is now in ruined condition, but some notable structures like fortification wall, bastions, mosques, stables, durgah, storage tanks, lakes, Chhatri etc are still in good condition and there is a need to preserve all these monuments as a cultural heritage.

\section{References}

1. Central provinces District Gazetteers Amraoti District (Valume-A) Bombay caxton works, Frere Road, 1911 Page-101.

2. Central provinces District Gazetteers Amraoti District (Valume-A) Bombay caxton works, Frere Road, 1911.

3. Central provinces District Gazetteers Amraoti District (Valume-A) Bombay caxton works, Frere Road, 1911

4. Central provinces District Gazetteers Amraoti District (Valume-A) Bombay caxton works, Frere Road, 1911 Page No. 105

5. Chitle S.K., Vidarbhati Kille (Marathi) Mangesh Publication Nagpur , 2005, Page No. 55

6. Naravane, M.S. (2014), Battles of the Honorourable East India Company A.P.H. Publishing corporation, ISBN - 9788131300343, Page No. 72, 73

7. Maharashtra State Gazetteers, Akola district $2^{\text {nd }}$ edition (Revised) 1977 Page No. 865.

8. Maharashtra State Gazetteers, Akola district $2^{\text {nd }}$ edition (Revised) 1977 Page No. 866

9. Maharashtra State Gazetteers, Akola district $2^{\text {nd }}$ edition (Revised) 1977

10. Hiralal - Inscriptions in C.P. and Barer, Government press, Nagpur, 1932, Page No. 147.

11. Desai, Z.A. Deccan Architecture (Manuscript in the Archaeological survey of India library) Nagpur Page No. 57

12. Maharashtra State Gazetteers, Akola district $2^{\text {nd }}$ edition (Revised) 1977 Page No. 870-871

13. Haig, T.W. Historical land Marks of the Deccan, Page No. 153

14. Maharashtra State Gazetteers, Akola district $2^{\text {nd }}$ edition (Revised) 1977 Page No. 867.

15. Maharashtra State Gazetteers, Akola district $2^{\text {nd }}$ edition (Revised) 1977 Page No. 841

16. Maharashtra State Gazetteers, Akola district $2^{\text {nd }}$ edition (Revised) 1977 Page No. 840

17. Kale Y. M. Varhadcha Itihasa Bharat Press. Pune, 1928, Page No. 78 